\title{
TEMA: ORAL HEALTH OF THE ELDERLY IN BRAZIL: SYSTEMATIC REVIEW
}

\section{AUTORES}

Éber Coelho Paraguassu ${ }^{1}$ and Jamille dos Passos Lacerda ${ }^{1}$ E-mail do autor correspondente: paraguassu84@yahoo.com.br

\section{INSTITUIÇÃO AFILIADA}

$\begin{array}{lrr}\text { 1-Departamento } & \text { de } & \text { Ciências } \\ \text { Odontológicas } & - \\ \text { GOE/UNIAVAN- } & \text { Macapá, } \\ \text { Amapá, Brasil. } & & \end{array}$

\section{CITAÇÃO}

PARAGUASSU, Éber Coelho, LACERDA , Jamille dos Passos. Oral health of the elderly in Brazil: Systematic review. Brazilian Journal of Implantology and Health Sciences, v.1, n.2, p. 25-33, 2019.

\section{PALAVRAS CHAVE}

Geriatric Dentistry; Oral Health; Oral hygiene

\section{ABSTRACT}

Introduction: The Brazilian population has undergone demographic changes over the years. This increase in life expectancy has resulted in the growth of the country's elderly population, necessitating giving people a aging with quality of life.

Objective: to report the oral health conditions of the Brazilian elderly, emphasizing the quality of life of the elderly, as well as the knowledge of the caregivers regarding the hygiene and maintenance of the oral health of this population.

Material and method: This is a bibliographical study, approaching the search of articles published in the last five years in Google Scholar and Scopus about "Oral Health Conditions of the Elderly in Brazil". The following descriptors were used: "dentistry", "elderly" and "oral health of the elderly". In the screening of articles, using the inclusion criteria, nineteen articles were studied, of which six articles published in 2014, nine articles published in 2015 and four articles published in 2019.

Conclusion: One can conclude with this work that there is a need for dental treatment aimed at this population, due to the pathologies from aging itself. 


\title{
Oral health of the elderly in brazil: systematic review
}

\begin{abstract}
Introduction: The Brazilian population has undergone demographic changes over the years. This increase in life expectancy has resulted in the growth of the country's elderly population, necessitating giving people a aging with quality of life.

Objective: to report the oral health conditions of the Brazilian elderly, emphasizing the quality of life of the elderly, as well as the knowledge of the caregivers regarding the hygiene and maintenance of the oral health of this population.

Material and method: This is a bibliographical study, covering the search for articles published in the last two years in the Scientific Electronic Library Online (SciELO) on "Health conditions mouth of the elderly in Brazil ". The following keywords were used: "dentistry", "elderly" and "oral health". In the screening of articles, using the inclusion criteria, nineteen articles were studied, of which six articles published in 2014, nine articles published in 2015 and four articles published in 2019.
\end{abstract}

Conclusion: One can conclude with this work that there is a need for dental treatment aimed at this population, due to the pathologies from aging itself.

Keywords: Aging; Geriatric Dentistry; Oral Health; Oral hygiene 


\section{INTRODUCTION}

Since the end of the 20th century Brazil has been by a demographic change with a sharp increase of the population over 60 years old [1]. This life expectancy contributes to the emergence of diseases typical of old age, with involvement of the stomatognathic, and, therefore, there is a greater need dental treatment aimed at this population [2].

For the elderly, the quality of life is related to the physiological, pathological, psychosocial, socio-cultural, economic and environmental. This quality of life directly influences the level offunctional impairment, morbidity and disability [3].

With aging, the body goes through some changes, and the mouth usually reflects, in theold age, the conditions in which these people lived. Such presented by changes in the oral cavity, such as caries, periodontal disease, edentulism, reduction of the salivary flow and the accumulation of dental biofilm [4].

This paper aims to report on the conditions of oral health of the Brazilian elderly; emphasizing the quality of life of the elderly, as well as the degree of knowledge of the caregivers with regard to hygiene and maintenance of oral health of these elderly people; through a review ofliterature on the subject.

\section{RESEARCH METHODOLOGY}

This is a bibliographical study of the quantitative. A search covers a search for articles published in the last two years in Scientific Electronic Online Library SciELO on the topic mouth of the elderly. " Used as keywords: "Dentistry", "elderly" and "oral health". How to include of publication, we opted for publications Portuguese and English languages available on the justified by the intention of the authors in Check the evolution of the theme in Brazil. The choice of base SciELO is justified by the fact that disseminated in regard to academic publications. Included to hold the panels between the years of 2014, 2015 and 2019, justified by the current demand for About the subject. Studies have been taken from other countries. In the 
Oral health of the elderly in brazil: systematic review

Éber Coelho Paraguassu and Jamille dos Passos Lacerda

screening of articles, using the inclusion criteria, nineteen articles were studied, of which six articles published in 2014, nine articles published in 2015 and four articles published in 2019.

\section{SYSTEMATIC REVIEW}

In Brazil, the transformation of the old pyramid population has generated major problems socioeconomic levels, since a greater number of people with the ability to enjoy more years of life nor always accompanied by health [5].

Population aging brought consequence, in addition to the increase in the demand for health, the increase of other modalities of care vulnerable or dependent elderly people, such as institutions for the elderly. Research show that the institutionalization of the elderly is due to such as: solitude associated with widowhood, minor opportunity, lower social support and low income, which have become more evident in recent years [1].

Nevertheless, in Brazil there are no specific rules concerning the oral health care of the elderly institutionalized, with the absence of protocols of procedures, the lack of care programming the lack of specialized training programs, as well as guidance and training of caregivers of the elderly. At most of the time, they do not have any training, which causes wear for both the elderly and the elderly, because they lack sufficient knowledge to guide the maintenance of oral health of the elderly [5].

There is a great lack of information regarding the knowledge on oral health in these institutions, especially with regard to the most common problems occur in the oral mucosa, since most caregivers sees the loss of teeth as something inherent in the aging [6].

Studies have analyzed the level of knowledge some caregivers who work in asylum institutions on the oral hygiene and maintenance of the oral health of the elderly and lack of cooperation was reported to be the largest difficulty encountered by caregivers during hygiene buccal of these $[5,19]$. 
Oral health of the elderly in brazil: systematic review

Éber Coelho Paraguassu and Jamille dos Passos Lacerda

The elderly consider oral hygiene to be a very personal activity, and most are not susceptible to suggestion. Therefore, the oral health care of the elderly institutionalized is sometimes complicated, most of which are caregivers, especially in care with your personal hygiene. However, among few independent appropriate oral health care before institutionalization [4].

Some studies have shown that oral pathologies found in the elderly are due to certain changes, such as the aging process, changes in the metabolic factors, nutritional factors, use of medications, of prostheses, psychopathological habits, use of alcohol and use of tobacco $[1,18]$.

Oral health in the elderly should be evaluated individually, since the physiological changes of the aging do not have the same pattern in the different organisms. Since, for many elderly patients, the dental treatment is still a challenge, depending on the motor and cognitive impairment present in large part of these $[3,17]$.

Studies show that caries and periodontal disease are the major public health problems in dentistry, reaching all ages and leading to tooth loss. Therefore, the promoting the health of the elderly ensures the well-being, the quality of life and selfesteem of these individuals, since results in proper mastication and aesthetics, enabling easy communication [6].

Therefore, oral health education, in addition to contribute to a better aesthetic, in the elderly, preserves the normal masticatory function and, as a result, the preservation tends to provide conservation of the teeth $[7,16]$.

\section{DISCUSSION}

Health must be understood as a link of the correct functioning organism with the union of the individual's physical, mental and intellectual well-being. Therefore, oral health and general health are related in a way that causes serious problems for the other. A precarious oral health condition can cause serious problems to the general health, because it affects the nutritional state, thus compromising the physical and mental well-being, therefore, it diminishes the quality of life and the 
pleasure of the social life of the individual. Likewise, general health may lead to oral problems. With the passage of age, some motor difficulties also develop, which may compromise the hygienization capacity, which is then made by relatives or caregivers [8].

Some studies find a relationship with regard to the oral health of the elderly, since they affirm that this special population needs to receive differentiated care $[9,10]$.

Aging leads to various physiological changes throughout the body. The prevention, information and proper care with oral hygiene in the adult population are of extreme importance, occurring this the teeth remained until the more advanced age.

With regard to the functional impacts on the quality of life of the elderly due to problems oral disorders; it was observed that these disorders would be associated to an unsatisfactory quality of life both in the physical and mental $[11,12,13,14]$.

Home dental care for the partially dependent and totally dependent elderly is characterized by a set of preventive actions and minimal intervention with the purpose of promoting oral health and guiding families and caregivers. These should also be prepared for the conditions of psychological management, which can lead to negative acceptance by the elderly. Many caregivers present difficulties and insecurity, thus requiring more instructions regarding the oral hygiene care of the elderly [15].

In Brazil there are no specific norms for the oral health care of institutionalized elderly, which reinforces the need for greater attention to this population, which often has neglected care.

\section{CONCLUSION}

It can be concluded with this work that with the technological advances and with the increase in life expectancy, healthier elderly people with low pathologies 
Oral health of the elderly in brazil: systematic review

Éber Coelho Paraguassu and Jamille dos Passos Lacerda

have been found, but those still harmful to the health of these elderly people if not treated and diagnosed early.

There is also a greater need for dental treatment aimed at this population, due to the pathologies caused by aging itself. Such knowledge enables health professionals to work on health promotion and disease prevention actions.

Considered to be of primordial physiological and metabolic importance, the oral cavity begins to suffer with the arrival of the age. In institutionalized elderly, this situation is even more critical in relation to the elderly population in general, due to the association of several systemic diseases, as well as precarious oral health care.

\section{CONFLICT OF INTEREST}

The author declares there are no conflicts of interest

\section{BIBLIOGRAPHIC REFERENCE}

1. Paula BG, Almeida MRB, Alves JFCS. Alterações bucais de idosos institucionalizados - Revisão de literatura. Rev Odontol Univ Cid São Paulo. 2014; 26(3):219-26.

2. Éber Coelho PARAGUASSU, Anneli Mercedes Celis de CARDENAS. Systematic Review of Current Medical Literature on the Impact of Oral Health on Quality of Life. International Journal of Advanced Engineering Research and Science, v.3, n.9, p. 115-123, 2019.

3. Rocha DA, Miranda AF. Atendimento odontológico domiciliar aos idosos: uma necessidade na prática multidisciplinar em saúde: revisão de literatura. Rev Bras Geriatr Gerontol. 2013; 16(1):181-9.

4. Oliveira JAG, Oliveira LLN, Cunha VPP. Considerações no tratamento em Odontogeriatria: relato de caso clínico. Arch Health Invest. 2014;3(6):1-5.

5. Silva BLA, Bonini JA, Bringel FA. Condição de saúde bucal de idosos institucionalizados em Araguaína/TO. Braz J Periodontol. 2015; 25(1):7-13. 
Oral health of the elderly in brazil: systematic review

Éber Coelho Paraguassu and Jamille dos Passos Lacerda

6. Alves VM, Tomo S, Simonato LE, Pereira AM, Boer NP, Cunha-Correia AS, Lima DP. Avaliação do conhecimento de cuidadores sobre a higiene bucal de pacientes idosos institucionalizados. Arch Health Invest. 2014; 3(5):9-15.

7. Monteiro TAS, Monteiro DCC, Monteiro MSS, Monteiro LSS, Lima LAA, Queiroz AAFLN. Cuidadores de idosos e atitudes frente à saúde bucal: uma revisão integrativa. Rev Enferm UFPI. 2013; 2(spe):102-7.

8. Chagas AM, Rocha ED. Aspectos fisiológicos do envelhecimento e contribuição da Odontologia na saúde do idoso. Rev Bras Odontol. 2012; 69(1):94

9. Rovida TAS, Peruchini LFD, Moimaz SAS, Garbin CAS. O conceito de saúde gera e bucal na visão dos cuidadores de idosos. Odontol Clín-Cient. 2013; 12(1):43-66.

10. Mestriner SF, Almeida ASQ, Mesquita LP, Bulgarelli AF, Mestriner Junior W. Condições de saúde bucal e qualidade de vida de idosos usuários do Sistema Único de Saúde. RGO. 2014; 62(4):389-94.

11. Lima TJV, Arcieri RM, Garbin CAS, Moimaz SAS, Saliba O. Humanização na atenção básica de saúde na percepção de idosos. Saude Soc.2014; 23(1):265-76.

12. Magalhães Junior HV, Tavares JC, Magalhães AAB, Galvão HC, Ferreira MAF. Caracterização da pressão da língua em idosos. Audiol Commun Res. $2014 ; 19(4): 375-9$.

13. PARAGUASSU, Éber Coelho et al. Qualidade de vida e satisfação em usuários de prótese total no estado do Amapá, Brasil. Revista Eletrônica Acervo Saúde, n. 27, p. e876-e876, 2019

14. Morais EF, Macedo RAP, Lira JAS, Lima KC, Borges BCD. Factors related to dry mouth and low salivary flow rates in diabetic elderly: a systematic literature review. Rev Bras Geriatr Gerontol. 2014; 17(2):417-23.

15. Batista FS, Gomes GAO, D'elboux MJ, Cintra FA, Neri AL, Guariento ME, et al. Relação entre força muscular de membros inferiores e independência funcional de idosos segundo critérios de fragilidade: um estudo transversal. São Paulo Med J. 2014; 132(5):282-9.

16. Martins AMEBL, Jones KM, Souza JGS, Pordeus IA. Associação entre impactos funcionais e psicossociais das desordens bucais e qualidade de vida entre idosos. Ciênc saúde coletiva. 2014; 19(8):3461-78.

17. Ferreira RC, Vargas AMD, Fernandes NCN, Souza JGS, Sá MAB, Oliveira LFB, et al. O idoso com comprometimento cognitivo apresenta pior condição de saúde bucal? Ciênc saúde coletiva. 2014;19(8):3417-28. 
Oral health of the elderly in brazil: systematic review

Éber Coelho Paraguassu and Jamille dos Passos Lacerda

18. PARAGUASSU, Éber Coelho; DE CARDENAS, Anneli Mercedes Celis. Sociodemographic characterization of users of total tissue-supported and implant-supported prostheses in the municipality of macapá, Brazil. International Journal of Development Research, v. 9, n. 02, p. 26081-26084, 2019.

19. Éber Coelho Paraguassu, Anneli Celis Mercedes de Cardenas, Marina Nolli Bittencourt, Ana Rita Pinheiro Barcessat and Paulo Fabricio Ramos. "Quality of life and satisfaction of users of total tissue-supported and implantsupported prostheses in the municipality of macapá, Brazil", International Journal of Development Research, 09, (02), 26007-26011, 2019 